\title{
Cell-Type-specific Regulation of Nerve Growth Factor (NGF) Synthesis in Non-neuronal Cells: Comparison of Schwann Cells with Other Cell Types
}

\author{
Ichiro Matsuoka, Michael Meyer, and Hans Thoenen \\ Department of Neurochemistry, Max Planck Institute for Psychiatry, D-8033 Planegg-Martinsried, Germany
}

\begin{abstract}
We have previously shown that after peripheral nerve lesion the synthesis of NGF is induced in cells of the nerve sheath (Heumann et al., 1987a). Further analysis led to the identification of growth factors and intracellular mechanisms responsible for this induction in sciatic fibroblasts (Lindholm et al., 1988; Hengerer et al., 1990). The present work aimed at the elucidation of the regulation of NGF synthesis in Schwann cells.
\end{abstract}

A variety of cytokines and peptide growth factors, including interleukin-1 (IL-1) and platelet-derived growth factor (PDGF), which are known to increase NGF-mRNA in fibroblasts and astrocytes, failed to do so in Schwann cell cultures. Forskolin (FK), an activator of adenylate cyclase, increased the level of NGF-mRNA eightfold within $3 \mathrm{hr}$ of incubation. The effect of FK on NGF-mRNA was mimicked by analogs of CAMP but not by dideoxyforskolin, an FK derivative not activating adenylate cyclase. Application of norepinephrine and isoproterenol also augmented the NGFmRNA content. Pretreatment of Schwann cells with $\mathrm{N}-[2-$ (methylamino)ethyl]-5-isoquinoline sulfonamide dihydrochloride (H-8), an inhibitor of cyclic-nucleotide-dependent protein kinases, decreased both basal and elevated levels of NGF-mRNA. Ionomycin, a $\mathrm{Ca}^{2+}$ ionophore, and phorbol 12-myristate 13-acetate (TPA), an activator of protein kinase $C$, potentiated the effect of $F K$ in an $\mathrm{H}-8$-sensitive manner. We show that the action of FK is independent of changes in mRNA stability and of protein synthesis. Thus, in cultured Schwann cells upregulation of NGF-mRNA expression seems to be mainly achieved by a CAMP-triggered transcriptional activation of the NGF gene. Another striking difference between various glial cell types was revealed by application of transforming growth factor $\beta-1$ (TGF- $\beta 1$ ), which is the strongest inducer of NGF-mRNA in cultured astrocytes (Lindholm et al., 1990). Schwann cells responded to TGF- $\beta 1$ by decreasing basal as well as FK-induced NGF-mRNA levels. Together with previously published work, our results show that cell-type-specific mechanisms not only account for the different control of NGF expression in neurons as compared

Received Feb. 11, 1991; revised Apr. 25, 1991; accepted May 2, 1991.

We acknowledge Dan Lindholm for valuable discussion and are grateful to Christel Lütticken and Maria Reitmayer for technical assistance. We thank YvesAlain Barde for critical reading and Lorraine Bale for linguistic revision of the manuscript.

Correspondence should be addressed to Hans Thoenen, Max Planck Institute for Psychiatry, Department of Neurochemistry, Am Klopferspitz 18A, $8033 \mathrm{Pla}$ negg-Martinsried, Germany.

Copyright (C) 1991 Society for Neuroscience $0270-6474 / 91 / 113165-13 \$ 05.00 / 0$ to glial cells, but also reveal a surprising specificity of regulatory mechanisms in different non-neuronal cell types, even those derived from the same tissue such as fibroblasts and Schwann cells of peripheral nerves.

Schwann cells are the glial cells of the PNS. They play an essential role in the formation of the microenvironment of the neuronal axons. Depending on the properties of the axons, they form myelin sheaths or ensheath the axons in nonmyelinated form (Weinberg and Spencer, 1975; Aguayo et al., 1976). Besides myelin proteins, Schwann cells synthesize components of the extracellular matrix (Bunge et al., 1980; Carey et al., 1983; Cornbrooks et al., 1983; McGarvey et al., 1984; Mehta ct al., 1985), cell adhesion molecules (Nieke and Schachner, 1985; Noble et al., 1985; Daniloff et al., 1986), and also neurotrophic factors such as NGF (Richardson and Ebendal, 1982; Rush, 1984; Assouline et al., 1987; Bandtlow et al., 1987). In the adult sciatic nerve, the contribution of the non-neuronal cells to the NGF supply for the NGF-dependent (sympathetic and subsets of neural crest-derived sensory; for review, see Levi-Montalcini and Angeletti, 1968; Thoenen and Barde, 1980) neurons is negligible (Heumann et al., 1987a). These neurons are trophically supported from their peripheral target tissues. However, after nerve lesion there is a massive increase in the synthesis of NGF by the sciatic non-neuronal cells (Heumann et al., 1987a,b). In situ hybridization experiments demonstrated that all the non-neuronal cells in the lesioned sciatic nerve, in particular Schwann cells and fibroblasts, express NGF-mRNA (Bandtlow et al., 1987; Heumann et al., 1987a). This lesion-mcdiatcd induction of NGFmRNA in the sciatic nerve occurs in a biphasic manner (Heumann et al., 1987a). The second prolonged increase is correlated with the immigration of macrophages. A causal relationship between these two phenomena could be deduced from the fact that in explants of sciatic nerve only the initial and not the second prolonged increase in NGF-mRNA could be observed. However, the biphasic in vivo situation could be mimicked by the addition of activated macrophages (Heumann et al., 1987b), and interleukin-1 (IL-1) was identified as a mediator of this prolonged elevation of NGF-mRNA (Lindholm et al., 1987). In further experiments, it has been demonstrated that fibroblasts, dissociated from adult rat sciatic nerve, also respond to IL-1 by an increase in NGF-mRNA (Lindholm et al., 1988). However, it was not clear whether NGF synthesis in Schwann cells, which represent the most abundant cell type of the sciatic ncrve, is regulated in a similar manner.

In the present experiments, we analyzed in Schwann cell culture the effects of those factors and cytokines that have previ- 
ously been shown to increase NGF-mRNA in other cell types, particularly in fibroblasts and astrocytes. Moreover, we investigated the effect of Schwann cell-axon interactions and finally second messenger systems that could be involved in the regulation of NGF-mRNA synthesis in Schwann cells. We report that none of the growth factors and cytokines tested increased NGF-mRNA levels in Schwann cells; however, forskolin (FK; an activator of adenylate cyclase), cAMP derivatives, and agonists of $\beta$-adrenergic receptors produced a marked increase in NGF-mRNA levels in Schwann cells. Transforming growth factor $\beta-1$ (TGF- $\beta 1$ ), the most powerful inducer of NGF-mRNA in astrocyte cultures (Lindholm et al., 1990), not only did not increase the NGF-mRNA levels in Schwann cells, but even reduced the basal level and abolished the increase initiated by FK in Schwann cells.

\section{Materials and Methods}

Materials. Dulbecco's modified Eagle's medium (DMEM), Ham's F12 medium, Minimal Essential Medium (MEM), penicillin, streptomycin, poly-L-lysine, cytosine- $\beta$-D-arabinofuranoside (Ara-C), mouse epidermal growth factor $(E G F),( \pm)$-norepinephrine, $(-)$-isoproterenol, $( \pm)$-metoprolol, clonidin, prostaglandin $\mathrm{E}_{2}$, forskolin ( $7 \beta$-acetoxy-8,13epoxy-1 $\alpha, 6 \beta, 9 \alpha$-trihydroxylabd-14-ene-11-one), ionomycin, phorbol 12 myristate 13-acetate (TPA), cycloheximide, actinomycin D, 8-bromocAMP (8-Br-cAMP), $N^{6}$-benzoyl-cAMP, and rat calcitonin gene-related peptide (CGRP) were purchased from Sigma (St. Louis). Human platelet-derived growth factor $\mathrm{AB}$ (PDGF-AB), porcine PDGF-BB, and TGF$\beta 1$ were purchased from British Bio-technology (Oxford), fetal calf serum (FCS) was from Boehringer Mannheim (Mannheim), 1-(5-isoquinolinesulfonyl)-2-methylpiperazine dihydrochloride (H-7) and $N$-[2(methylamino)ethyl]-5-isoquinoline sulfonamide dihydrochloride ( $\mathrm{H}-8$ ) were from Seikagaku Kogyo (Tokyo), and EHS laminin was from GIBCO-BRL (Eggenstein, Germany). We gratefully acknowledge the generous gifts of the following materials: human recombinant IL- $1 \beta$ and IL- $1 \alpha$ (Biogen, Geneva) by courtesy of Drs. A. Gronenborn (Max Planck Institute for Biochemistry, Martinsreid) and P. Wingfield (Biogen, Geneva), bovine recombinant basic fibroblast growth factor (bFGF) (Progen, Heidelberg) by courtesy of Dr W. Risau (Max Planck Institute for Psychiatry), human recombinant insulin-like growth factors I and II (IGF-I and IGF-II) from Dr. A. Skottner of Kabi Peptide Hormone (Stockholm), and the ganglioside mixture (composition: GM1:GD1a: GD1b:GT1b = 20:43:15:19), originally prepared by Fidia, Italy, from Drs. Y. Arakawa and H. Ozawa of Eisai Pharmaceuticals Co. Ltd. (Tokyo). NGF purified from mouse submandibular gland (for reference, see Saadat et al., 1989), brain-derived neurotrophic factor (BDNF) purified from pig brain (Hofer and Barde, 1988), and ciliary neurotrophic factor (CNTF) purified from rat sciatic nerves (Saadat et al., 1989) were provided by Drs. H. Rohrer, Y.-A. Barde, and M. Sendtner, respectively, from our laboratory. Batches of protein factors from commercial sources used in this study have shown biological activity in other systems (for IL- $\alpha$, IL-1 $\beta$, EGF, bFGF, PDGF: Spranger et al., 1990; for IGF-I and IGF-II: Arakawa et al., 1990). Neurotrophic factors purified in the laboratory (NGF, BDNF, CNTF) were fully active in the appropriate bioassay. All the other chemicals were of reagent grade.

Cell and orgun culture. Schwann cells were prepared by a modification of published methods (Porter et al., 1986). Sciatic nerves were dissected from $2-3$-d-old Wistar rats and treated with $0.1 \%$ collagenase (Sigma) in $\mathrm{Ca}^{2+}-\mathrm{Mg}^{2+}$-free PBS for $40 \mathrm{~min}$ and further incubated with $0.1 \%$ trypsin for $20 \mathrm{~min}$. After trituration with a Pasteur pipette, dissociated cells were plated on $6 \mathrm{~cm}$ dishes in DMEM supplemented with $10 \%$ FCS $(10 \%$ FCS/DMEM) and antibiotics $(100 \mathrm{U} / \mathrm{ml}$ penicillin and 0.1 $\mathrm{mg} / \mathrm{ml}$ streptomycin). Cells were exposed to two cycles of Ara-C treatment $(10 \mu \mathrm{M})$ for $3 \mathrm{~d}$ each to eliminate proliferating fibroblasts. After $7 \mathrm{~d}$, cells were washed, split, and plated on poly-L-lysine-coated $6 \mathrm{~cm}$ dishes in $10 \%$ FCS/DMEM containing $10 \mu \mathrm{M}$ FK and antibiotics. The cells were cultured for a maximum of $8 \mathrm{~d}$ in the presence of FK. Once confluent, medium was changed to $10 \%$ FCS/DMEM containing antibiotics followed by the same medium change every third day. Expanded Schwann cells were subcultured once more for experiments after at least 1 week without FK. Purity of Schwann cells was higher than $98 \%$ when evaluated by immunostaining for NGF receptor (Chandler et al., 1984) [antibody MC192 was a generous gift of Drs. E. Shooter (Stanford University) and M. Hosang (Hoffman-LaRoche, Basel)] and S-100 protein, which in the PNS is a specific marker for Schwann cells (Stefansson et al., 1982) (rabbit anti-cow S-100 from Dako, Copenhagen).

Adult rat sciatic fibroblasts and explant cultures of rat sciatic nerve segments were prepared as described by Lindholm et al. (1988) and Heumann et al. (1987b), respectively.

The medium used for stimulation of cells and nerve segments was $10 \%$ FCS/DMEM unless otherwise stated. Where specified, 1\% FCS/ DMEM or a serum-free medium consisting of a 1:1 mixture of Ham's F12 medium and MEM containing a modified $\mathrm{N}_{2}$ supplement (containing $30 \mathrm{~nm}$ selenium, $100 \mu \mathrm{m}$ putrescine, $5 \mu \mathrm{g} / \mathrm{ml}$ insulin, and $1 \mathrm{mg} /$ $\mathrm{ml}$ transferrin, but no progesterone) was used (Bottenstein and Sato, 1979).

Sympathetic neurons were obtained from superior cervical ganglia of newborn rats and cultured in serum-free medium (see Saadat et al., 1989).

$R N A$ preparation and Northern blot analysis. Total RNA was prepared from cells and tissue that had been kept frozen after stimulation according to the method of Chomczynski and Sacchi (1987). The extraction buffer contained $20 \mathrm{pg}$ of a 0.51 -kilobase $(\mathrm{Kb})$-long NGF standard RNA to evaluate the recovery of mRNA. Total RNA samples and different amounts of full-length NGF-mRNA standard were glyoxylated, electrophoresed through a $1.5 \%$ agarose gel, and then transferred to a nylon membrane (Hybond-N, Amersham). Following transfer, membranes were fixed by UV irradiation, prehybridized, and hybridized with ${ }^{32} \mathrm{P}$-labeled NGF-cRNA probe $(0.92 \mathrm{~Kb})$ at $68^{\circ} \mathrm{C}$ in $50 \%$ formamide (see Heumann et al., 1987a). The membranes were washed and exposed to Fuji RX films at $-80^{\circ} \mathrm{C}$ for $12-36 \mathrm{hr}$. The amount of cellular NGFmRNA present was quantified by densitometric scanning (LKB Ultroscan $\mathrm{XL}$ ) of the autoradiograms and correction for RNA recovery.

NGF ELISA. The amount of NGF in the medium of Schwann cells was measured by a sensitive two-site ELISA (Korsching and Thoenen, 1983) with recently described modifications (Spranger et al., 1990).

\section{Results}

\section{Effect of peptide growth factors on $N G F-m R N A$ levels in} cultured Schwann cells

Expression of NGF-mRNA levels in cultured Schwann cells prepared from newborn rat sciatic nerves was examined by Northern blot. Schwann cells kept in serum-containing medium (10\% FCS/DMEM) and in serum-free medium contained 5.63 $\pm 2.30(n=35)$ and $2.00 \pm 0.99(n=7) \mathrm{pg}$ of NGF-mRNA $10^{6}$ cells, respectively. Addition of $10 \%$ FCS to Schwann cells kept in serum-free medium led to a gradual increase in NGFmRNA levels that did not become apparent before at least 24 $\mathrm{hr}$ after medium change. This is in contrast to the rapid and massive response of astrocytes to serum (Spranger et al., 1990). Since the present study was initiated by the previously observed more than 10-fold increase in NGF-mRNA levels after lesion of the sciatic nerve, we focused our attention on changes in NGF-mRNA levels of more than twofold.

IL-1 has been shown to increase NGF-mRNA levels in a variety of systems, including explant culture of sciatic nerve segments, fibroblasts isolated from sciatic, astrocytes in culture, and hippocampus in vivo (Lindholm et al., 1987, 1988; Spranger et al., 1990). PDGF has also been shown to increase NGFmRNA levels in explant cultures of sciatic nerve segments (Lindholm et al., 1987). EGF and bFGF were shown to augment NGF-mRNA levels in cultured astrocytes (Spranger et al., 1990). Therefore, Schwann cells were treated with growth factors and cytokines including PDGF (AB and BB), EGF, bFGF, IGF-I, IGF-II, and IL- $1 \beta$ for $3-6 \mathrm{hr}$, either individually in the presence of various serum concentrations $(10 \%, 1 \%$, or serum-free) or after pretreatment with FK $(24-48 \mathrm{hr})$. None of these conditions revealed an influence of growth factors or cytokines on the NGFmRNA levels in Schwann cells (for incubation with individual factors, see Table 1). IL-l $\alpha$ also had no effect. In addition, we 


\begin{tabular}{lccc}
\hline $\begin{array}{l}\text { Table 1. Effects of peptide growth factors and cytokines on the level of NGF-mRNA in cultured } \\
\text { Schwann cells }\end{array}$ & & \\
& & Time & NGF-mRNA \\
Factor & Concentration & $(\mathrm{hr})$ & $(\%$ of control) \\
\hline EGF & $10 \mathrm{ng} / \mathrm{ml}$ & 3 & 100 \\
& & 6 & 81 \\
bFGF & $20 \mathrm{ng} / \mathrm{ml}$ & 3 & 84 \\
& & 6 & 95 \\
IGF-I & $1 \mu \mathrm{g} / \mathrm{ml}$ & 6 & $84^{a}$ \\
& & 12 & $110^{a}$ \\
IGF-II & $0.5 \mu \mathrm{g} / \mathrm{ml}$ & 6 & $95^{a}$ \\
& & 12 & $100^{a}$ \\
Porcine PDGF-BB & $10 \mathrm{ng} / \mathrm{ml}$ & 4 & 95 \\
& & 6 & $94^{a}$ \\
Human PDGF-AB & $10 \mathrm{ng} / \mathrm{ml}$ & 3 & $92^{a}$ \\
& & 6 & $82^{a}$ \\
IL-1 & 12 & $86^{a}$ \\
NGF & $30 \mathrm{U} / \mathrm{ml}$ & 6 & $99 \pm 16^{b}$ \\
BDNF & $50 \mathrm{ng} / \mathrm{ml}$ & 3 & 99 \\
& & 6 & 70 \\
CNTF & $30 \mathrm{ng} / \mathrm{ml}$ & 3 & 76 \\
\end{tabular}

Schwann cells $\left(0.4-0.6 \times 10^{6}\right.$ cells) were treated with factors in serum-free medium (EGF and bFGF) or $10 \%$ FCS/ DMEM medium (rest of the factors) for the indicated time before extraction. The data are the mean of duplicate determinations unless indicated otherwise.

${ }^{a}$ Single determination.

${ }^{n}$ Mean $\pm \mathrm{SD}(n=5)$.

tested neurotrophic proteins, which are synthesized in the sciatic or by Schwann cells. However, the addition of NGF, BDNF, and CNTF had no essential effects on the NGF-mRNA content (Table 1). The effect of TGF- $\beta 1$ is described separately.

\section{Effect of axonal contact}

In the adult animal, Schwann cells exist in close axonal contact. To study the influence of axonal contact, we analyzed a neuronSchwann cell coculture system. Pure cultures of superior cervical ganglionic neurons from newborn rats, which in the presence of NGF extended a rich neurite network on laminin, were replenished with pure Schwann cells. Nearly all Schwann cells established contact with axons and maintained contact for the entire culture period (Fig. 1). After $3 \mathrm{~d}$ in vitro, the cocultures were stimulated with IL- $1 \beta$ or FK (see below for the stimulatory effect of FK on pure Schwann cell cultures). Coculture did not result in IL- $1 \beta$ responsiveness, nor did it change the induction of NGF-mRNA by FK (data not shown). Basal levels of NGFmRNA were elevated approximately 1.5-2-fold compared to isolated Schwann cells. This may be due to the initiation of Schwann cell proliferation by axonal contact (Wood and Bunge, 1975).

Gangliosides have been reported to increase steady state NGF levels in culture medium of Schwann cells (Ohi et al., 1990). In our experiments, a mixture of gangliosides obtained from the same source and applied at $1 \mathrm{~mm}$ (average concentration) for 3-24 hr to Schwann cells cultures did not result in any significant increase in NGF-mRNA levels (data not shown).

\section{Regulation of the NGF-mRNA level in Schwann cells by} CAMP

Effect of FK, cAMP analogs, and $\beta$-adrenergic receptor agonists. Treatment of Schwann cells cultivated in $10 \% \mathrm{FCS} / \mathrm{DMEM}$ with FK, a reversible activator of adenylate cyclase, for $6 \mathrm{hr}$ resulted in a six-to eightfold increase in NGF-mRNA levels, irrespective of the presence of IL-1 $\beta$ (Fig. 2, upper lanes). In serum-free medium, although the basal levels of NGF-mRNA are decreased, FK still exerted a 2.7-fold induction of NGF-mRNA (Fig. 2, lower lanes). Treatment of Schwann cells with 8-BrcAMP and $N^{6}$-benzoyl-c $\Lambda$ MP, membrane-permeable analogs of cAMP, also increased the NGF-mRNA (Fig. 3A). The order of potency of cAMP analogs (i.e., $N^{6}$-benzoyl-cAMP $>8$-Br-cAMP) was in accordance with other cAMP-dependent systems such as lipolysis in adipocytes (Beebe et al., 1984). Dideoxyforskolin, a FK analog that possesses most of the cAMP-independent effects of FK but lacks the ability to activate adenylate cyclase (see Laurenza et al., 1989), did not increase NGF-mRNA levels (Fig. 3A). The ineffectiveness of 8-bromo-cGMP (8-Br-cGMP) indicates that activation of guanylate cyclase does not play a role in induction of NGF-mRNA.

Norepineprine and isoproterenol, $\beta$-adrenergic receptor agonists already shown to increase cAMP levels in Schwann cells (Yasuda et al., 1988), also increased NGF-mRNA to levels similar to those achieved by FK treatment (Fig. $3 B$ ). In contrast, clonidin, an $\alpha$-adrenergic receptor agonist that does not affect c $\triangle M P$ levels, did not change the NGF-mRNA content. The induction of NGF-mRNA by norepinephrine was abolished by metoprolol, a specific $\beta_{1}$-adrenergic receptor antagonist (Fig. $3 B$ ). CGRP, which has been reported to increase cAMP in other cell types (Laufer and Changeux, 1987; Villar et al., 1989), did not give significant changes in the NGF-mRNA levels in Schwann cells (1.3-fold increase for CGRP).

Primary Schwann cells that were prepared from newborn rat sciatic nerve and Ara-C treated as described but without expansion by FK also responded to FK by an increase in NGFmRNA levels comparable to expanded cultures. Again, they did not respond to IL-1 (data not shown). This observation indicates that FK administered in order to achieve the large cell numbers necessary for the Northern blot experiments does not permanently change the regulation of NGF synthesis in Schwann cells. 


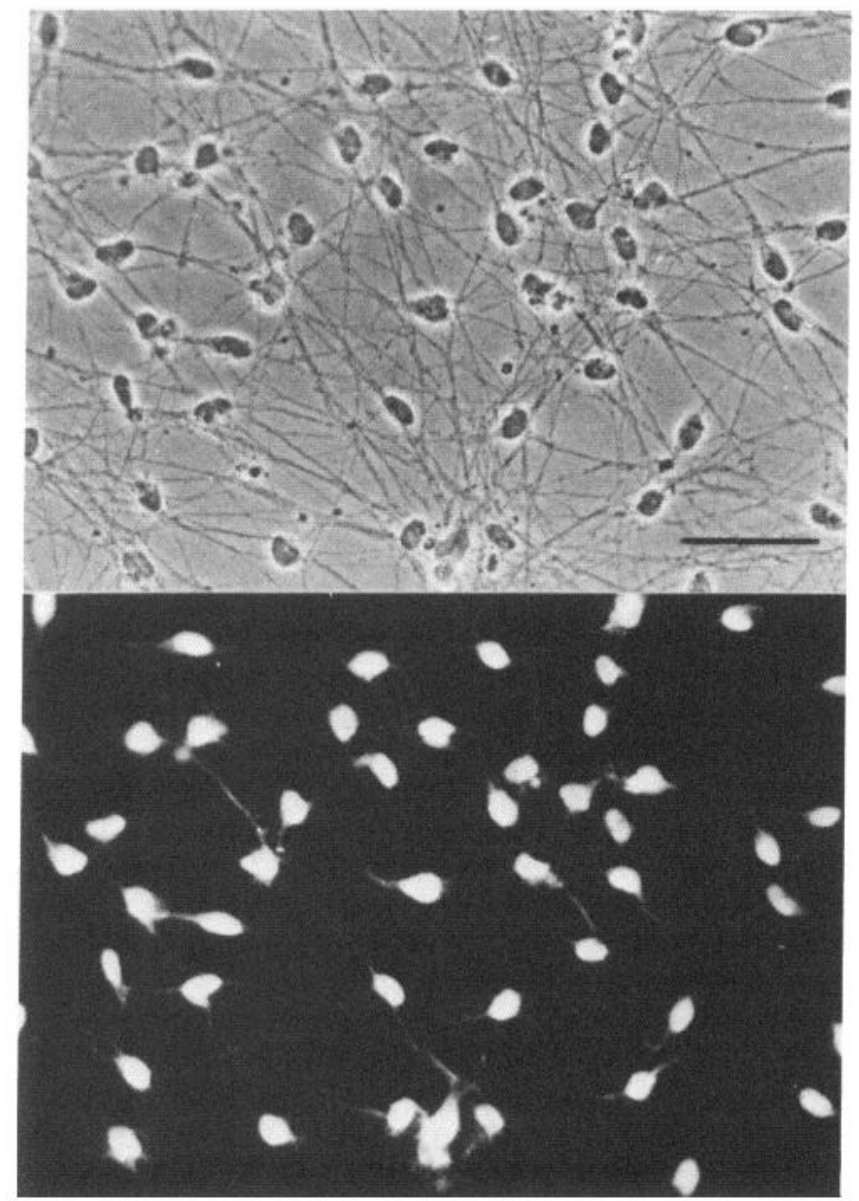

Figure 1. Schwann cells in contact with axons. Neurons were prepared from newborn rat superior cervical ganglia and allowed to form extensive neurite network for 3 weeks. Schwann cells were then plated directly on the neurite network and further maintained in culture for $3 \mathrm{~d}$. Top, Phase-contrast micrograph. Bottom, Immunostaining of Schwann cells for S-100. Scale bar, $50 \mu \mathrm{m}$.

The concentration dependence of the FK induction of NGFmRNA in Schwann cells was measured. As shown in Figure $4 A$, NGF-mRNA in serum-containing medium was maximally (8.3fold) induced by $30 \mu \mathrm{M} F K$, and the half-maximal concentration was approximately $6 \mu \mathrm{M}$. These values are in the same range as those reported for the elevation of intracellular cAMP by FK (Seamon and Daly, 1981). The concentration dependence of NGF-mRNA induction by FK in serum-free medium was similar to that in serum-containing medium (data not shown).

Analysis of the time course of the FK effect on NGF-mRNA (Fig. $4 B$ ) showed that the level of NGF-mRNA increased drastically between 1 and $3 \mathrm{hr}$ after the addition of $10 \mu \mathrm{M} F K$, reached a plateau between 3 and $6 \mathrm{hr}$, and thereafter gradually decreased to less than twofold at $24 \mathrm{hr}$ (Fig. $4 B$ ). The level of NGF-mRNA $48 \mathrm{hr}$ after addition of FK was almost equal to the basal level before exposure to FK. Induction of NGF-mRNA by $0.1 \mathrm{~mm}$ isoproterenol showed kinetics similar to that of FK, reaching its maximum at $3 \mathrm{hr}$ (Fig. 4B). However, the level of NGFmRNA returned to the basal level $6 \mathrm{hr}$ after addition of isoproterenol. This effect may be due to the desensitization of the $\beta$-adrenergic receptor.

Modification of the FK effect by ionomycin and TPA. Treatment of Schwann cells for $3 \mathrm{hr}$ with $1 \mu \mathrm{g} / \mathrm{ml}$ ionomycin, a $\mathrm{Ca}^{2+}$ ionophore, slightly increased the NGF-mRNA level (twofold from the basal level; Fig. $5 A, B$ ). However, when ionomycin was added together with FK at $20 \mu \mathrm{M}$, where the FK effect itself was almost maximal (see Fig. 4A), the NGF-mRNA level in Schwann cells increased markedly to 15 -fold the basal level (approximately twofold the level increased by FK alone; Fig. $5 A, B$ ). This effect of ionomycin was abolished by $5 \mathrm{~mm}$ EDTA, a chelator of divalent cations (data not shown). Application of ionomycin together with either $0.1 \mathrm{~mm}$ norepinephrine or $0.1 \mathrm{~mm}$ isoproterenol again resulted in a synergistic increase of the NGFmRNA, reaching a level 12-fold higher than the basal level (data not shown).

TPA, a phorbol ester and potent activator of protein kinase (PKC), exerted opposite effects on the basal as compared to FKinduced levels of NGF-mRNA in Schwann cells. Treatment of Schwann cells with $0.1 \mu \mathrm{g} / \mathrm{ml}$ TPA for $3 \mathrm{hr}$ significantly reduced the basal level of NGF-mRNA (to approximately $30 \%$ of the basal level), while treatment with TPA in the presence of FK remarkably increased the NGF-mRNA to a level (approximately 13-15-fold of basal level) similar to the level induced by combination of ionomycin and FK (Fig. 5A,B). Treatment of Schwann cells with ionomycin, TPA, and FK all at one time elevated the level of NGF-mRNA slightly more than either of the combinations ionomycin and FK or TPA and FK.

Effects of inhibitors of protein phosphorylation. In mammalian systems, most of the effects of elevated cAMP on cellular events are shown to be mediated by activation of cAMP-dependent protein kinase (PKA) (Edelman et al., 1987). Therefore, we investigated the putative role of protein phosphorylation in the regulation of NGF gene expression using the protein kinase inhibitors $\mathrm{H}-7$ and $\mathrm{H}-8$. In a cell-free system, $\mathrm{H}-7$ was shown to be selective for $\operatorname{PKC}\left(K_{i}=6.0 \mu \mathrm{M}\right)$, while $\mathrm{H}-8$ is more selective for PKA $\left(K_{i}=1.2 \mu \mathrm{M}\right)$ than for PKC $\left(K_{i}=15 \mu \mathrm{M}\right)$ (Hidaka et al., 1989). As shown in Figure $5 B$, pretreatment of Schwann cells with $\mathrm{H}-7$ up to $50 \mu \mathrm{M}$ did not reduce the levels of NGFmRNA in most of the conditions used. However, the effect of a combination of TPA and FK was reduced by $50 \mu \mathrm{M}$ H-7 close to that achieved by FK alone, suggesting a role of PKC activation in the enhancement of FK action. On the other hand, pretreatment of Schwann cells with $50 \mu \mathrm{M} \mathrm{H}-8$ drastically reduced the NGF-mRNA levels under all experimental conditions tested (Fig. 5B). Thus, H-8 suppressed not only the effect of FK, but also the potentiating effects of TPA and ionomycin. It also reduced the basal NGF-mRNA levels to nearly undetectable values.

Effects of cycloheximide. Cycloheximide, an inhibitor of protein synthesis, is known to affect the levels of various mRNAs by eliminating short-lived proteins responsible for either transcriptional repression or destabilization of mRNAs (Shaw and Kamen, 1986). As shown in Figure 6, incubation of Schwann cells with $10 \mu \mathrm{g} / \mathrm{ml}$ cycloheximide for $3 \mathrm{hr}$ resulted in an increase in NGF-mRNA levels comparable to the level measured after FK treatment. Concomitant application of cycloheximide and FK to Schwann cells resulted in an additive effect on NGFmRNA levels, suggesting that synthesis of transcriptional activators is not required for the action of FK.

Stability of the NGF-mRNA in Schwann cells. The half-life of NGF-mRNA was measured by following the time course of the decay of NGF-mRNA after the addition of actinomycin D, a transcriptional inhibitor, to cells stimulated with FK, ionomycin, or cycloheximide (Fig. 7). The results are summarized in Table 2. NGF-mRNA in Schwann cells without stimulation 


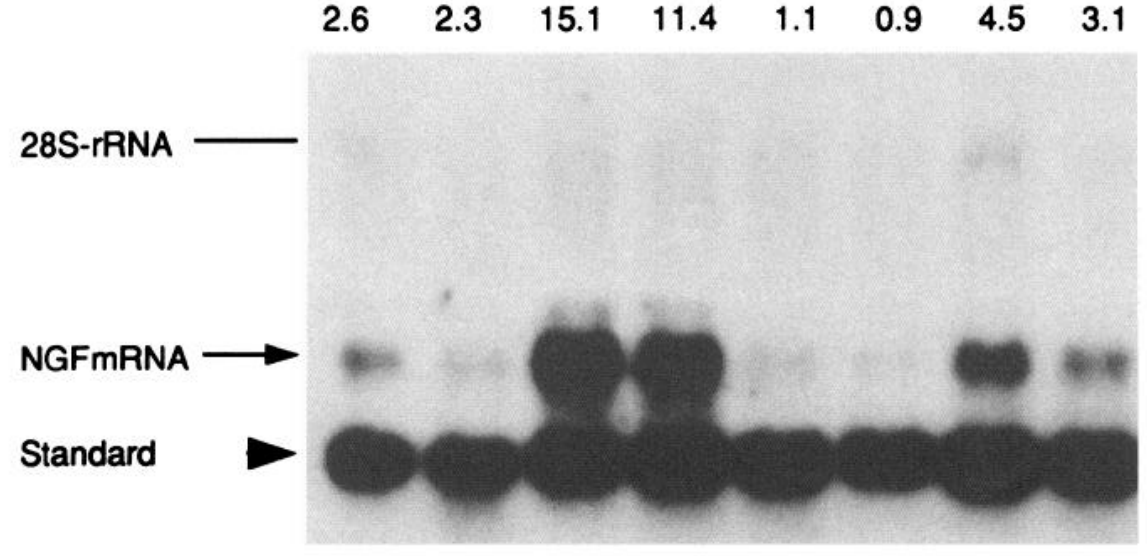

(pg)

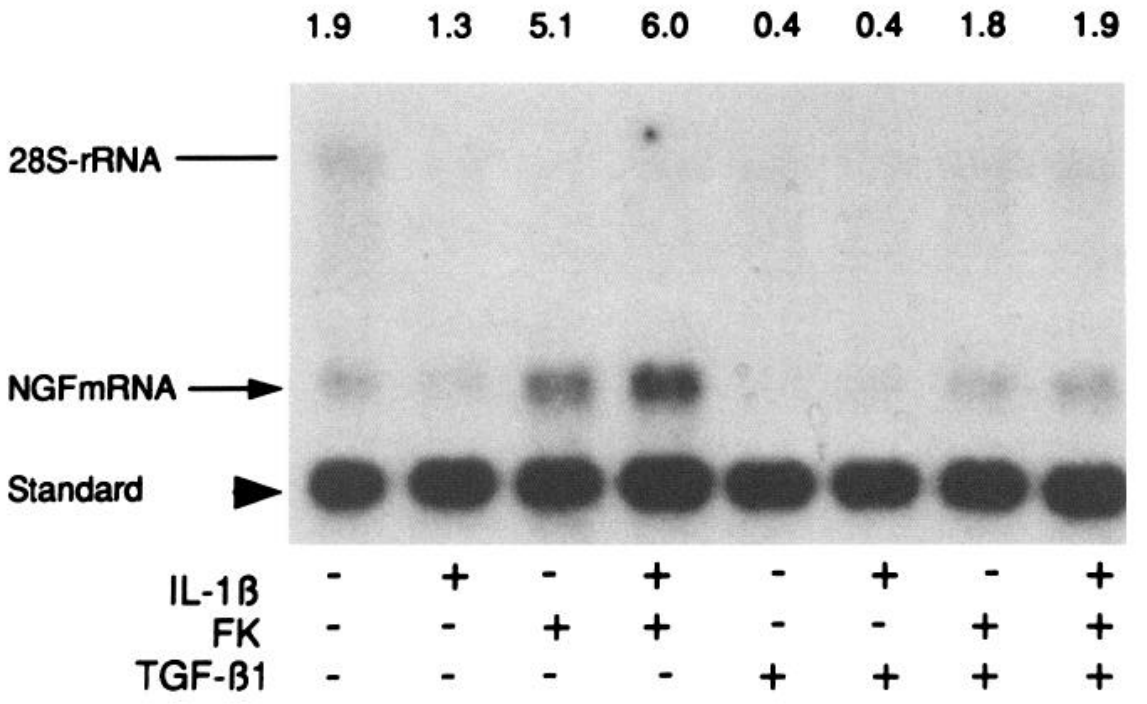

Figure 2. Northern blot analysis of NGF-mRNA in Schwann cells. Schwann cells $\left(6 \times 10^{s}\right.$ cells $/$ dish $)$ kept in serum-containing medium $(10 \%$ FCS/DMEM; upper lanes) or serum-free medium (lower lanes) for $24 \mathrm{hr}$ were treated with FK $(10 \mu \mathrm{M})$ for another 6 $\mathrm{hr}$ before the cells were frozen. Where indicated, the cells were treated with IL- $1 \beta(30 \mathrm{U} / \mathrm{ml})$ for the last $3 \mathrm{hr}$ before freezing or pretreated with TGF- $\beta 1$ ( 2 $\mathrm{ng} / \mathrm{ml}$ ) starting $6 \mathrm{hr}$ before addition of FK. The short length standard $(0.51 \mathrm{~Kb}$, $20 \mathrm{pg} / \mathrm{sample}$ ) was included in the extraction buffer to allow for correction of RNA recovery, and its position is indicated by the arrowhead. The position of the full-length NGF-mRNA (1.4 $\mathrm{Kb})$ is indicated by the arrow. Values above lanes indicate the absolute amount of NGF-mRNA (pg) after correction for RNA recovery. had a half-life $\left(t^{1 / 2}\right)$ of $0.67 \mathrm{hr}$. Cycloheximide clearly prolonged the half-life 3.4-fold, suggesting that at least part of its effect is on the stabilization of NGF-mRNA. On the other hand, FK, which increased the NGF-mRNA content to higher levels than cycloheximide, did not significantly prolong the half-life of NGFmRNA. Ionomycin, which increased the steady state NGFmRNA level about twofold, also failed to prolong the lifetime, while the combination of FK and ionomycin prolonged the halflife about twofold.

\section{Effect of TGF- $\beta 1$ on NGF-mRNA levels in Schwann cells}

It has recently been reported that TGF- $\beta 1$ and TGF- $\beta 2$ are mitogenic for rat sciatic Schwann cells and act synergistically with FK on the proliferation of these cells (Eccleston et al., 1989;

Table 2. Stability of NGF-mRNA in Schwann cells

\begin{tabular}{llll} 
Addition & Half-life $\left(t_{y_{2}}\right)$ of NGF-mRNA & \multicolumn{1}{c}{$\begin{array}{l}\text { Level of } \\
\text { NGF- } \\
\text { mRNA }^{b} \\
\text { (relative) }\end{array}$} \\
\cline { 2 - 4 } No addition & $\mathrm{hr}$ & Relative $^{a}$ & 1 \\
Ionomycin & 0.67 & 1 & 1.85 \\
FK & 0.76 & 1.13 & 3.93 \\
FK + ionomycin & 0.85 & 1.27 & 12.6 \\
Cycloheximide & 1.5 & 2.24 & 2.86 \\
\hline
\end{tabular}

Values are calculated from the experiments of Figure 7.

${ }^{a}$ Relative to half-life determined for nontreated cells.

${ }^{b}$ Amount of NGF-mRNA after drug treatments just before actinomycin D addition. Values are given relative to nontreated cells. 
A
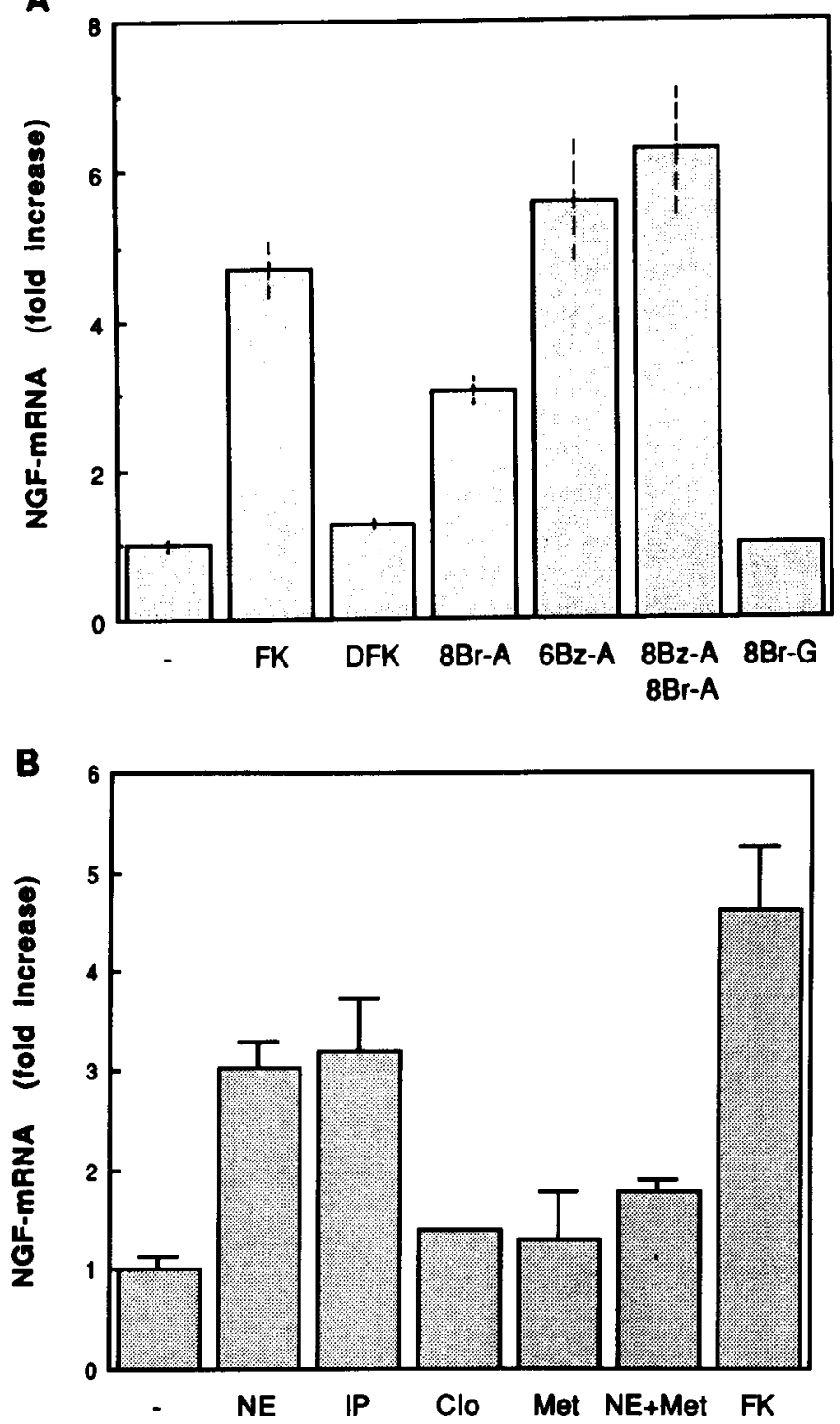

Figure 3. Effect of FK and cAMP analogs and $\beta$-adrenergic receptorrelated substances on the level of NGF-mRNA in Schwann cells. $A$, Schwann cells were incubated with $10 \mu \mathrm{M} F K, 10 \mu \mathrm{M}$ dideoxyforskolin $(D F K), 1 \mathrm{~mm} 8$-bromo-cAMP $(8 B r-A), 0.5 \mathrm{~mm} N^{6}$-benzoyl-cAMP $(6 B z-$ $A), 1 \mathrm{mM} \mathrm{8-bromo-cGMP}(8 B r-G)$, or a combination thereof for $6 \mathrm{hr}$. $B$. Schwann cells were incubated in the presence of $0.5 \mathrm{~mm} 3$-isobutyl1-methylxanthine (IBMX) with $0.1 \mathrm{~mm}$ norepinephrine $(N E), 0.1 \mathrm{mM}$ isoproterenol $(I P), 0.1 \mathrm{~mm}$ clonidin $(\mathrm{Clo}), 0.1 \mathrm{~mm}$ metoprolol $(\mathrm{Met}), 10$ $\mu_{\mathrm{M}} F K$, or their combination for $3 \mathrm{hr}$. Northern blot analysis was performed as in Figure 2. Levels of NGF-mRNA were calculated as described in Materials and Methods. In $A$, each column represents the mean and range (indicated by broken lines) of duplicate samples except for $8 B r-G$ (single determination). In $B$, each column represents the mean and SD of triplicate samples except for Met and $N E+M e t$ (duplicate determinations) and Clo (single determination).

Ridley et al., 1989). Furthermore, TGF- $\beta 1$ increased the NGFmRNA levels in astrocytes in culture 50-fold (Lindholm et al., 1990). These observations prompted us to examine the effect of TGF- $\beta 1$ on the level of NGF-mRNA in Schwann cells in the presence and absence of FK. As shown in Figure 2, treatment of Schwann cells with TGF- $\beta 1(2 \mathrm{ng} / \mathrm{ml})$ decreased the NGFmRNA levels both in the presence and absence of serum. As

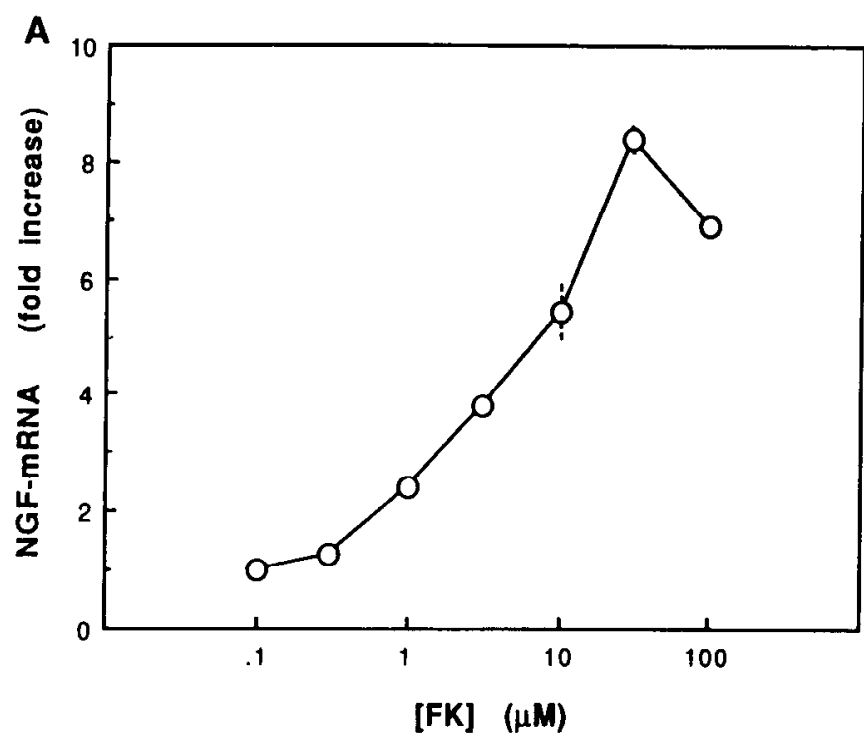

B

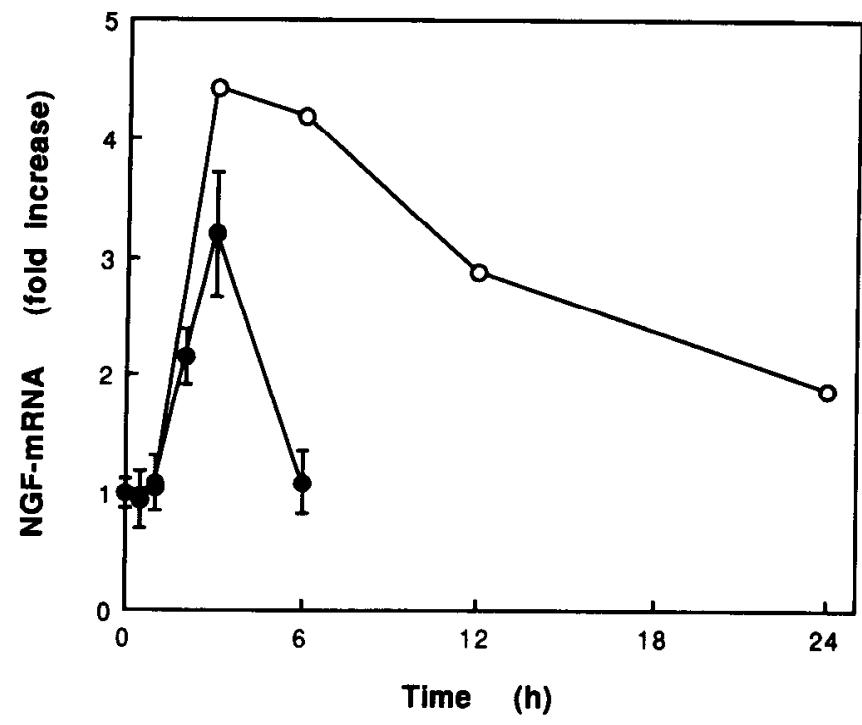

Figure 4. Dose- and time-dependent increase by FK of the level of NGF-mRNA in Schwann cells. $A$, Dose-response. Schwann cells were incubated with the indicated concentration of FK for $6 \mathrm{hr}$ before freezing. Each data point represents the mean and range (indicated by the broken line) of duplicate samples. $B$, Time course. Schwann cells were frozen at the indicated time after addition of $10 \mu \mathrm{M}$ FK (open circles). A representative of three independent experiments is shown. Time course of NGF-mRNA increase induced by $100 \mu \mathrm{M}$ isoproterenol in the presence of $0.5 \mathrm{~mm}$ 3-isobutyl-1-methylxanthine is also shown (solid circles; mean $\pm \mathrm{SD} ; n=3$ ).

shown in Figure 8A, the basal level of NGF-mRNA started to decrease between $3-6 \mathrm{hr}$ after addition of TGF- $\beta 1$. We analyzed the minimal time of pretreatment necessary for the effect of TGF- $\beta$. When Schwann cells were pretreated with TGF- $\beta 1$ for various periods before addition of FK for another $3 \mathrm{hr}$, a significant inhibition of TGF- $\beta 1$ on the FK-induced NGF-mRNA became detectable with pretreatment periods longer than $6 \mathrm{hr}$ (Fig. $8 B$ ). When TGF- $\beta 1$ was added simultaneously with FK, the inhibitory effect of TGF- $\beta 1$ started after $6 \mathrm{hr}$ (data not shown). The effect of TGF- $\beta 1$ was transient, since it was not observed after $24 \mathrm{hr}$ pretreatment (Fig. $8 B$ ). The effect of TGF$\beta 1$ was maximal at $2 \mathrm{ng} / \mathrm{ml}$ (Fig. $8 C$ ). 
A
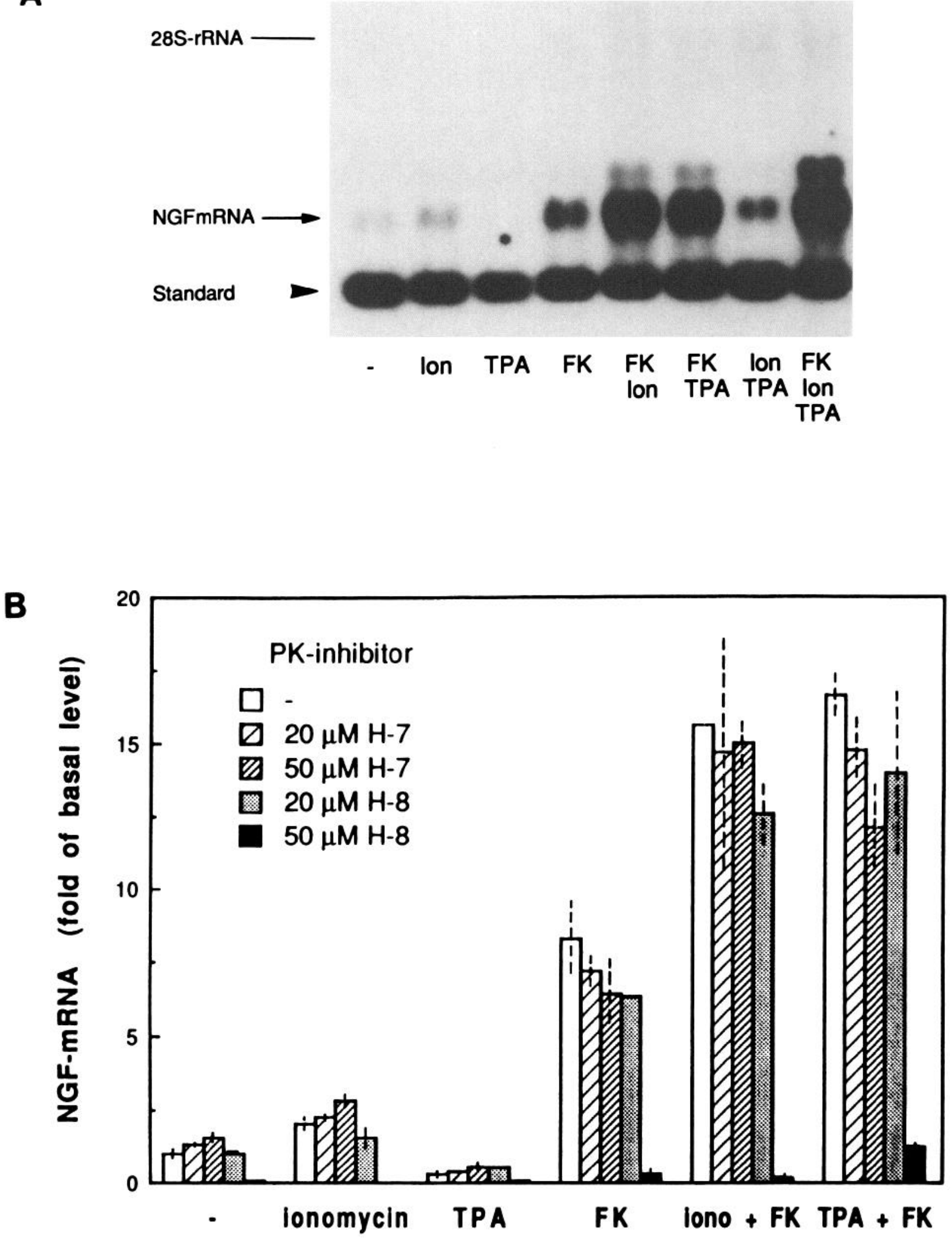

Figure 5. Effect of $\mathrm{Ca}^{2+}$ ionophore, TBA, FK, and inhibitors of protein phosphorylation on the level of NGF-mRNA. A, Schwann cells were treated for $3 \mathrm{hr}$ with a combination of the following reagents: ionomycin $($ Ion; $1 \mu \mathrm{g} / \mathrm{ml}), T P A(0.1 \mu \mathrm{g} / \mathrm{ml})$, and $F K(20 \mu \mathrm{M})$. B, Schwann cells were pretreated with 20 or $50 \mu \mathrm{M}$ of $H-7$ or $H-8$ for $0.5 \mathrm{hr}$ and then $F K(20 \mu \mathrm{M})$, ionomycin $($ iono $; 1 \mu \mathrm{g} / \mathrm{ml})$, and $T P A(0.1 \mu \mathrm{g} / \mathrm{ml})$ or combinations thereof were added for another $3 \mathrm{hr}$. Each data point represents the mean and range (indicated by broken lines) of duplicate samples. 


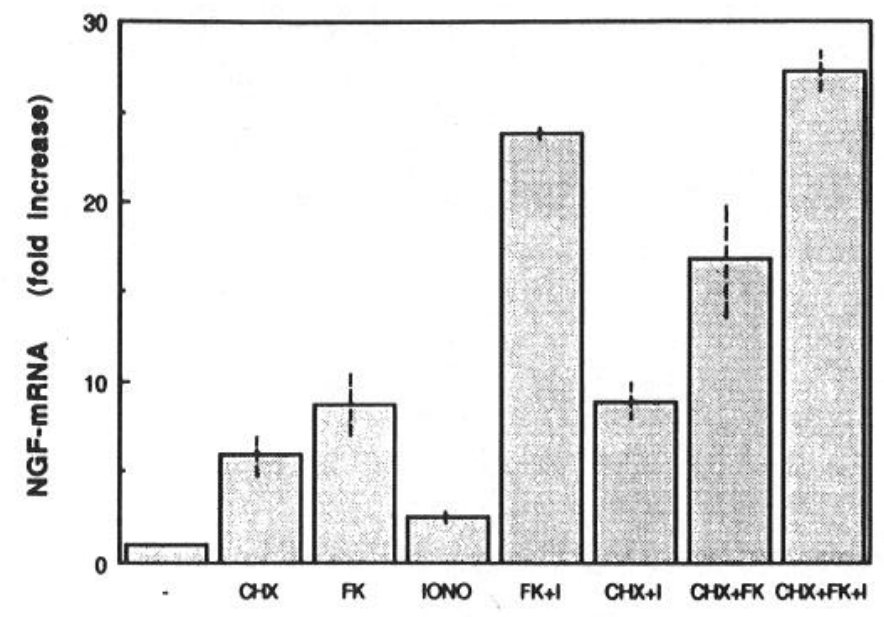

Figure 6. Effect of cycloheximide on the level of NGF-mRNA. Schwann cells were treated for $3 \mathrm{hr}$ with the following reagents: cycloheximide $(C H X ; 10 \mu \mathrm{g} / \mathrm{ml})$, ionomycin $(I O N O$ or $I ; 1 \mu \mathrm{g} / \mathrm{ml})$, or $F K(20 \mu \mathrm{M})$ or combinations thereof. Each data point represents the mean and range (indicated by broken lines) of duplicate samples.

\section{Effect of FK, ionomycin, and TGF- $\beta 1$ on the concentration of $N G F$ protein in the medium of Schwann cell cultures}

NGF protein accumulating in the culture medium during $24 \mathrm{hr}$ incubation with FK, ionomycin, and TGF- $\beta 1$ was measured by a two-site ELISA (Fig. 9). FK increased the NGF concentration 1.7-fold. Concomitant application of FK and ionomycin showed a remarkable increase in the NGF concentration (4.6-fold). TGF$\beta 1(4 \mathrm{ng} / \mathrm{ml})$, added together with FK, abolished the FK-induced increase in NGF protein in agreement with the effect of TGF$\beta 1$ on the NGF-mRNA as described above. TGF- $\beta 1$ added alone also gave a small decrease in basal NGF concentration. Our intention was to demonstrate that the changes of NGFmRNA levels are paralleled by changes in the amount of secreted protein. Therefore, we did not attempt to optimize the recovery of NGF protein from Schwann cell conditioned medium by the inclusion of protease inhibitors.

Comparison of the effects of FK and IL-I on the NGF-mRNA levels in nerve organ culture and sciatic fibroblasts

To assess the question whether FK also acts in the complex, nondissociated tissue, we performed experiments on newborn and adult rat sciatic nerve organ culture and fibroblasts prepared from adult rat sciatic. As shown in Figure 10A, treatment of explant culture of newborn rat sciatic nerve segments (animals were of the same age as those used for Schwann cell preparation) with IL- $1 \beta$ for $3 \mathrm{hr}$ increased NGF-mRNA eightfold. FK at 20 $\mu \mathrm{M}$ also increased the NGF-mRNA significantly (fivefold). Ionomycin, which itself had no effect, enhanced the response to FK increasing the NGF-mRNA levels sevenfold. Ionomycin did not further elevate the IL- $1 \beta$-mediated increase in NGF-mRNA levels (data not shown). In adult sciatic nerve explant culture, $20 \mu \mathrm{M}$ FK had an efficacy almost equivalent to that of IL-1 $\beta$ (Fig. 10B). Ionomycin did not further enhance the effect of either IL- $1 \beta$ or FK. In cultures of fibroblasts prepared from adult rat sciatic nerves, FK was less effective than IL-1 $\beta$ (Fig. 10C).

\section{Discussion}

A major concern regarding the in vitro approach chosen in this study may be its relevance for the in vivo situation. Schwann

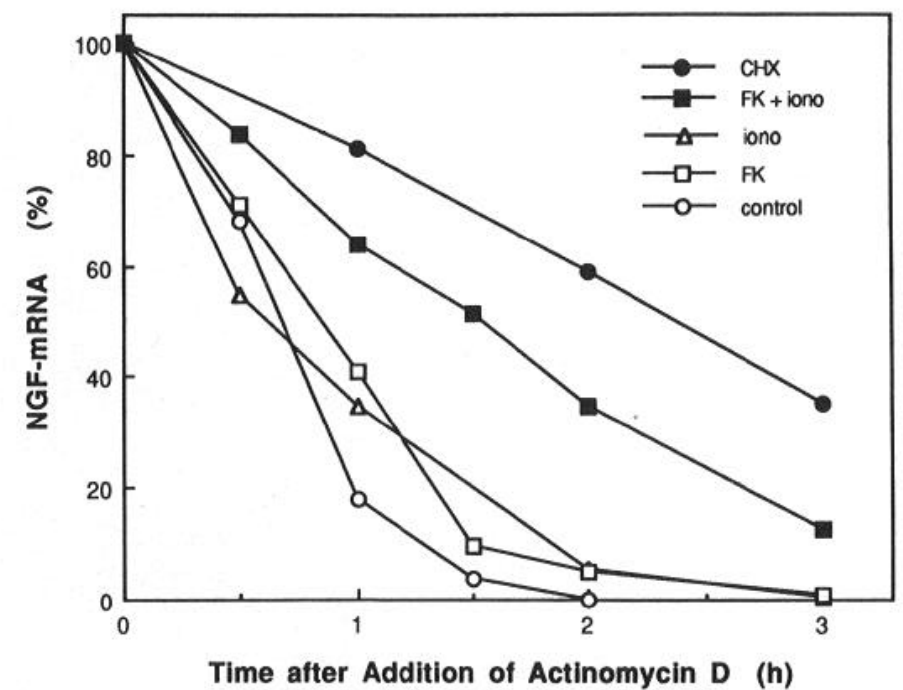

Figure 7. Stability of NGF-mRNA in Schwann cells. Schwann cells were treated with $F K(20 \mu \mathrm{M})$, ionomycin $($ iono $; 1 \mu \mathrm{g} / \mathrm{ml})$, or cycloheximide $(C H X ; 10 \mu \mathrm{g} / \mathrm{ml})$ for $4 \mathrm{hr}$. Then transcription was blocked by adding $10 \mu \mathrm{g} / \mathrm{ml}$ actinomycin $\mathrm{D}$, and cells were further incubated for the indicated time. The NGF-mRNA levels at $4 \mathrm{hr}$ (before addition of actinomycin D) are set at $100 \%$. Each data point represents the mean of two to four samples (each individual data point did not deviate more than $15 \%$ from the mean).

cells prepared from sciatic nerve and stimulated to proliferate in vitro have been shown to retain basic Schwann cell properties and remain functionally competent (Dubois-Dalcq et al., 1981; Porter et al., 1986; Rutkowski et al., 1990). Particularly, the effects of the compounds used for cell selection and induction of Schwann cell proliferation are reversible. This interpretation is supported by our observation that the expansion of the Schwann cell cultures by FK did not change the regulation of NGF-mRNA. Furthermore, the regulation by cAMP was largely independent of the cell environment and was detected in purified cultures as well as in nondissociated nerve segments and Schwann cell-neuron coculture. Since for technical reasons large numbers of Schwann cells could only be obtained from newborn animals, we also analyzed the response to IL-1 and FK of newborn in comparison to adult nerve organ culture. No age-dependent differences in NGF-mRNA regulation were detectable.

In the following, we discuss the main characteristics of NGF regulation in Schwann cells, that is, the ineffectiveness of growth factors to increase NGF-mRNA levels and possible molecular mechanisms responsible for the regulation by cAMP; moreover, we emphasize the striking differences between the NGF regulation in Schwann cells and that in various other cell types.

\section{Regulation by growth factors}

The available data show that IL-1 is a potent regulator of NGFmRNA expression in sciatic nerve and fibroblasts (Lindholm et al., 1987, 1988). IL-1 has also been shown to increase NGFmRNA in cells and tissues of the CNS, that is, in cultured astrocytes and in the hippocampus after intraventricular injection (Spranger et al., 1990). The inability of Schwann cells to respond to IL-1 does not seem to be due to lack of IL-1 receptors, since by using iodinated IL-1 we found specific IL-1 binding sites on Schwann cells with an affinity constant comparable to that described for typical IL-1 responding cells (M. Meyer and H. Thoenen, unpublished observations). Furthermore, prelim- 

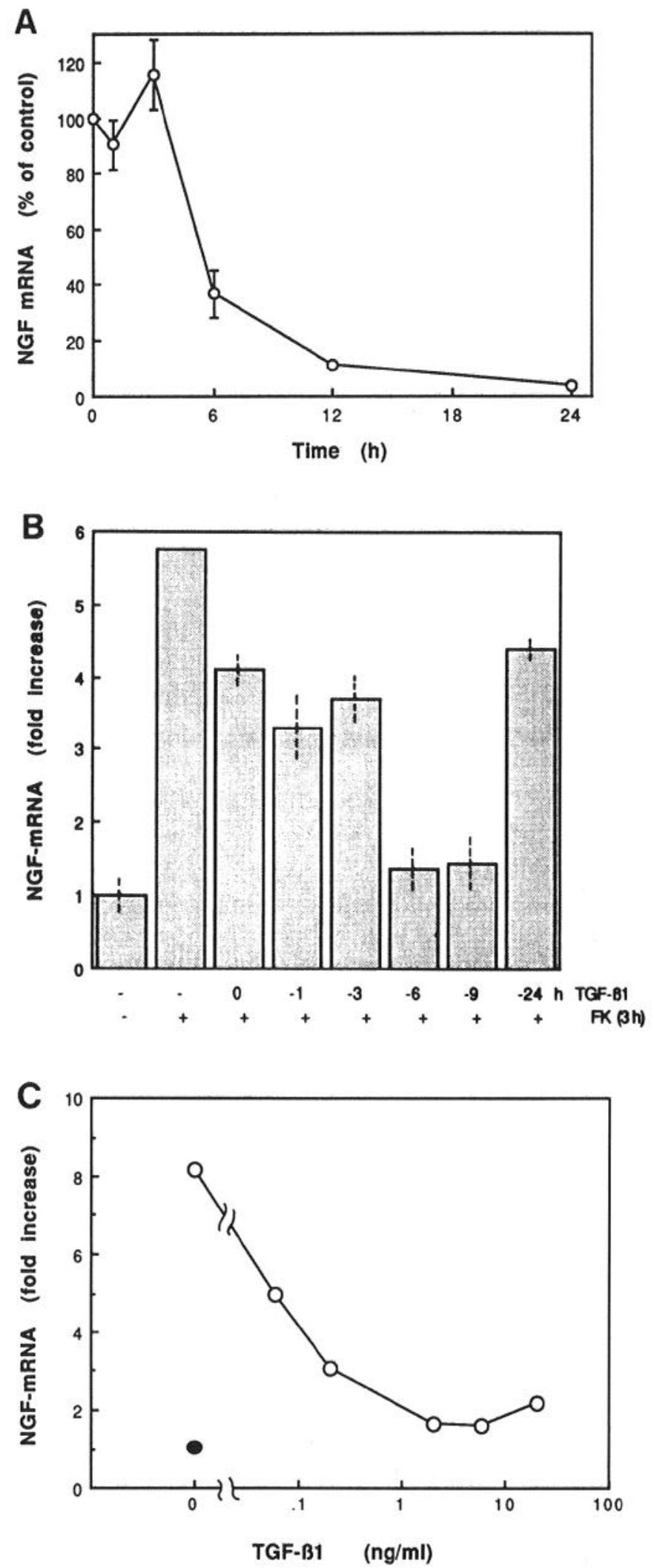

Figure 8. Effect of TGF- $\beta 1$ on the level of NGF-mRNA in Schwann cells. $A$, Effect of TGF- $\beta 1$ on the basal level of NGF-mRNA. Schwann cells were treated with $2 \mathrm{ng} / \mathrm{ml}$ TGF- $\beta 1$ for the time indicated. $B$, Effect of TGF- $\beta 1$ on the FK-stimulated level of NGF-mRNA. Schwann cells were preincubated with $4 \mathrm{ng} / \mathrm{ml}$ TGF- $\beta 1$ for the time indicated and then further incubated with $20 \mu \mathrm{M}$ FK for $3 \mathrm{hr}$. Broken lines indicate the range of duplicate samples. $C$, Dose dependence of the TGF- $\beta 1$

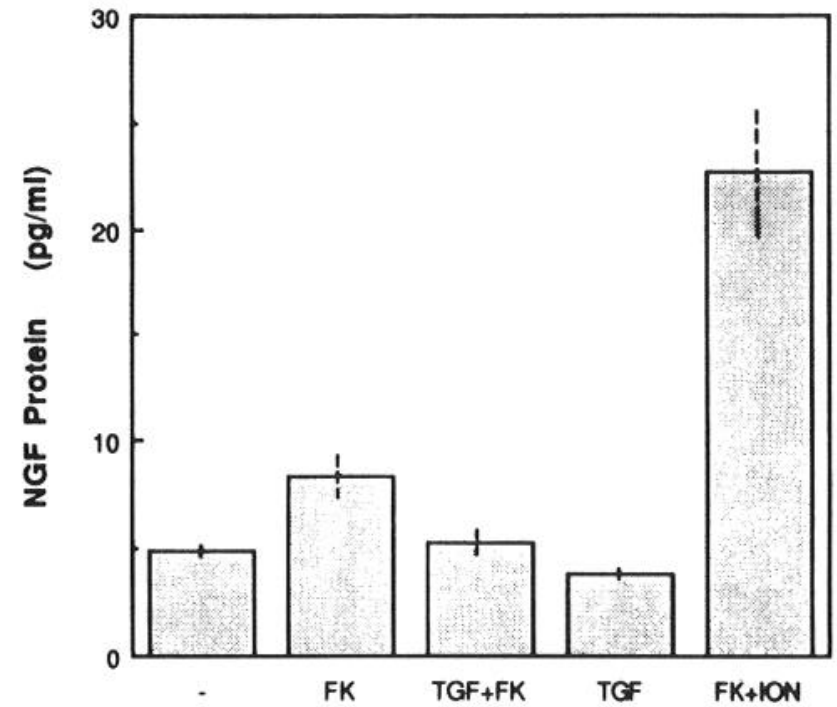

Figure 9. Effect of FK and TGF- $\beta 1$ on the NGF concentration in the medium of Schwann cells. Schwann cells were incubated with fresh $10 \%$ FCS/DMEM $(1 \mathrm{ml})$ that contained $20 \mu \mathrm{M} \mathrm{FK}, 4 \mathrm{ng} / \mathrm{ml} \mathrm{TGF}-\beta 1$, or 1 $\mu \mathrm{g} / \mathrm{ml}$ ionomycin $(I O N)$, or their combination for $24 \mathrm{hr}$. After the incubation period, the culture medium was collected and the NGF concentration was measured by ELISA. Each data point indicates mean and range (indicated by broken lines) of duplicate samples.

inary quantification of IL-1 bioactivity in Schwann cell conditioned medium gave no indication of autocrine IL-1 production, which could result either in saturation of the IL-1 response or in desensitization. This suggests that the Schwann cell IL-1 receptor, in contrast to its counterpart on astrocytes and fibroblasts, is functionally uncoupled from intracellular mechanisms of NGF regulation. Our Schwann cell-neuron coculture experiments show that coupling does not simply depend on axonal contact, although it may be argued that our culture conditions did not warrant an in vivo type of contact. We cannot exclude that culture conditions that promote extensive ensheathment and basal lamina formation (Bunge et al., 1986) would give different results. Our experiments revealed a similar situation for PDGF and bFGF. In Schwann cells, these growth factors regulate cell proliferation and c-fos mRNA levels (Ratner et al., 1988; Davis and Stroobant, 1989; Weinmaster and Lemke, 1990), but, again in contrast to astrocytes (Spranger et al., 1990), they have no effect on the levels of NGF-mRNA. Since Schwann cells possess the low-affinity NGF receptor (DiStefano and Johnson, 1988; Yasuda et al., 1987), we tested the possibility of a feedback control. However, addition neither of NGF nor of the structurally related BDNF (Leibrock et al., 1989) resulted in any significant change of NGF-mRNA levels. Also, CNTF, which is produced by Schwann cells in the intact sciatic nerve (Lin et al., 1989; Stöckli et al., 1989), did not significantly change NGFmRNA levels.

Surprisingly, TGF- $\beta 1$ downregulated NGF-mRNA levels in Schwann cells. A similar rather slow action of TGF- $\beta$ has been

effect on the level of NGF-mRNA. Schwann cells were incubated first with TGF- $\beta 1$ at the indicated concentrations for $6 \mathrm{hr}$, and then the cells were further incubated with $20 \mu \mathrm{M}$ FK for $3 \mathrm{hr}$ (open circles). The basal level of NGF-mRNA of the cells without FK and TGF- $\beta 1$ treatments is also indicated (solid circle). A typical example of two independent experiments with similar results is shown for $A-C$. 


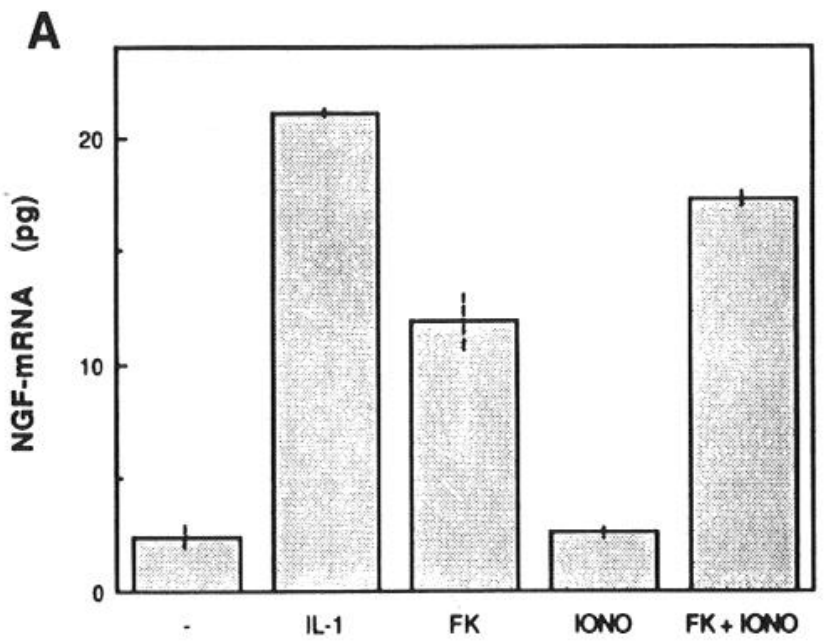

B
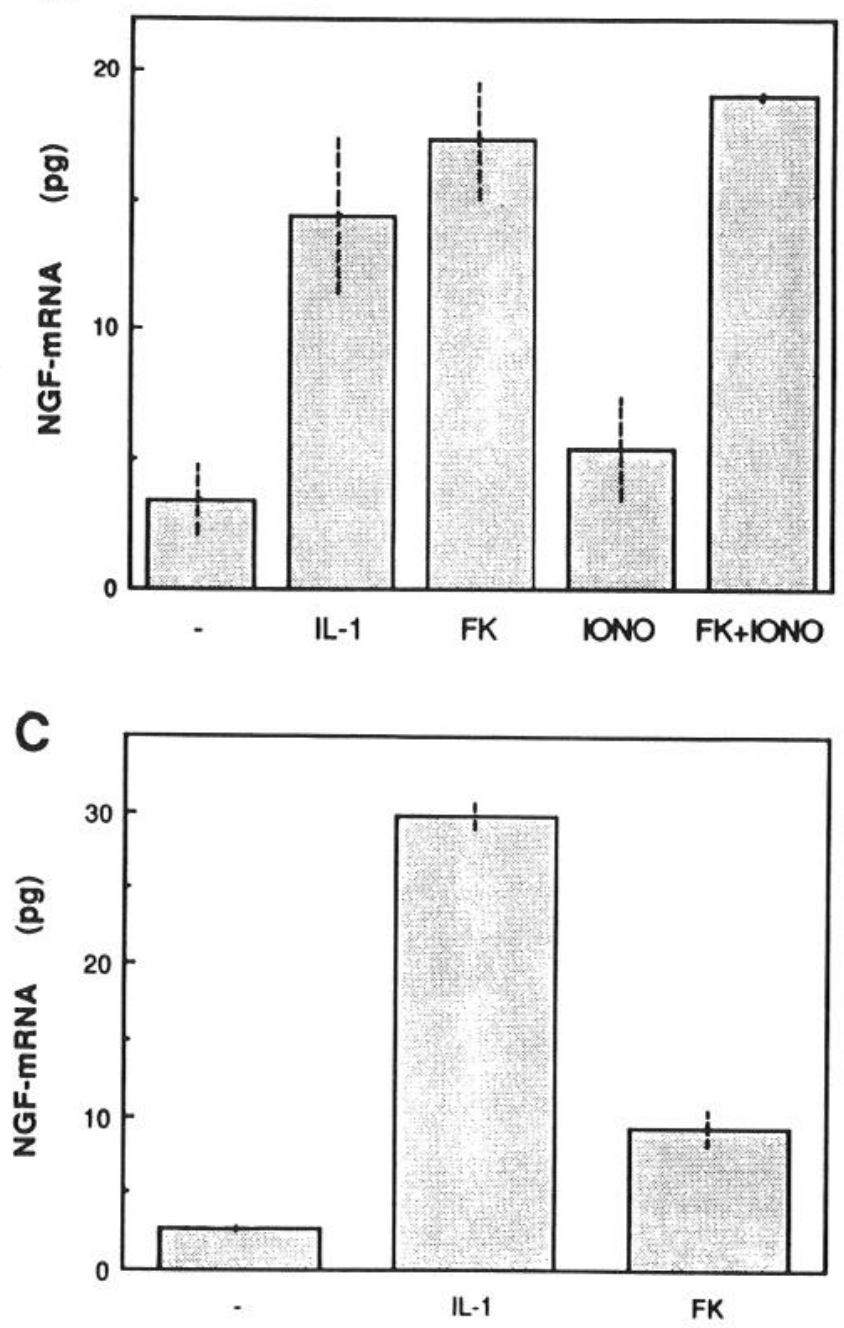

Figure 10. Comparison of the effects of IL-1 $\beta$ and FK on the levels of NGF-mRNA in explant culture of sciatic nerve from newborn $(A)$ and adult $(B)$ rats and fibroblasts from adult sciatic nerve $(C)$. Nerve explants and fibroblasts were incubated with $I L-1(60 \mathrm{U} / \mathrm{ml}), F K(20$ $\mu \mathrm{M})$, or ionomycin $(I O N O ; 1 \mu \mathrm{g} / \mathrm{ml})$ or combinations for $3 \mathrm{hr}$. Each column gives the absolute amount of NGF-mRNA (pg/explant). The mean and range (indicated by broken lines) of duplicate samples are given. described in endothelial cell culture, where the effects of bFGF were suppressed by TGF- $\beta$ (Saksela et al., 1987). The molecular basis for these differences in NGF-mRNA regulation between astrocytes and Schwann cells remains to be elucidated. Cisacting sequences mediating transcriptional repression by TGF- $\beta$ have been identified in the promoter of the transin gene (Kerr et al., 1990); however, differences in the trans-acting factors would have to account for cell type specificity.

\section{Mechanism of regulation by adenylate cyclase}

As a second approach for analyzing NGF regulation in Schwann cells, we analyzed the involvement of second messengers. Using different analogs of FK and cAMP, we have shown that the major signal transduction pathway leading to an increase in NGF-mRNA levels in Schwann cells involves activation of adenylate cyclase, whereas PKC activation resulted in decreased NGF-mRNA levels. This is in contrast to the situation described for fibroblasts (Wion et al., 1990). Activation of adenylate cyclase via the $\beta_{1}$-adrenergic receptor also resulted in augmented NGF-mRNA levels. This adenylate cyclase-dependent pathway is not specific for Schwann cells; small increases in NGF-mRNA occurring after adenylate cyclase activation have also been demonstrated in rat primary astrocytes (Schwartz and Mishler, 1990), in glioma cells (Dal Toso et al., 1988; Schwartz, 1988), and in the present study in fibroblasts derived from the sciatic. Although protein kinase inhibitors are not absolutely selective for specific kinases, considering the exclusive effectiveness of H-8 we propose protein kinase A activation as the next step of the signaling pathway. FK increases the NGF-mRNA levels in Schwann cells with kinetics comparable to those in systems where a relationship between transcriptional activation by cAMP and increase in steady state mRNA is established (e.g., Sasaki et al., 1984; Schmid et al., 1987). In agreement with the assumption of transcriptional activation of the NGF gene by FK, we did not observe any major influence of FK on NGF-mRNA stability. Preliminary transfection experiments using NGF-promoter/chloramphenicol acetyl transferase (CAT) constructs showed that CAT activity is inducible by FK, confirming its action at the transcriptional level (I. Matsuoka, M. Meyer, and H. Thoenen, unpublished observations). It will be interesting to see whether a typical cAMP response element (CRE), for example, as described for the somatostatin gene promoter (for review, see Montminy et al., 1990) or a different sequence, is involved. A multiplicity of trans-acting factors involved in cAMP-mediated transcriptional activation have been identified (for an overview, see Habener, 1990; Ziff, 1990).

Although cAMP seems to be an essential factor regulating NGF expression in Schwann cells, the modulatory effects of $\mathrm{Ca}^{2+}$ ionophore and phorbol ester point to a complex regulation. It should again be stressed that the potentiating effects of these drugs were $\mathrm{H}-8$ sensitive and dependent on adenylate cyclase activation. The molecular basis for these observations may be found either in posttranslational modifications of trans-acting factors (Gonzalez et al., 1989; Sheng et al., 1990; Van Nguyen et al., 1990) or by effects on upstream elements of the signaling pathway, such as modification of adenylate cyclase activity (Sugden et al., 1985; Rozengurt et al., 1987; Yoshimasa et al., 1987).

Observations made in fibroblasts and glioma cells suggest that synthesis of the immediate early gene product, c-Fos protein, plays an important role in the regulation of NGF-mRNA (Mocchetti et al., 1989; Hengerer et al., 1990). The c-Fos-dependent transactivation of the NGF gene in fibroblasts is mediated via 
an activator protein 1 (AP-1) site located in the first intron of the NGF gene (Hengerer et al., 1990). However, in Schwann cells the relationship between the expression of c-Fos protein and NGF is not established. Conditions that lead to high levels of expression of c-fos InRNA and AP-1 binding activity (e.g., TPA or serum addition; M. Meyer, I. Matsuoko, and H. Thoenen, unpublished observations) in Schwann cells do not result in increased NGF-mRNA expression (see Results). These observations may suggest that functional AP-1 complex formed in Schwann cells after the appropriate stimulation can not, in contrast to fibroblasts, interact with the intronic AP-1 site of the NGF gene and/or other components of the transcription apparatus in a way necessary for transcriptional activation of the NGF gene. In contrast to astrocytes and fibroblasts, where cycloheximide had an inhibitory effect on the induction of NGFmRNA (Mocchetti et al., 1989; Hengerer et al., 1990; Lindholm et al., 1990; Wion et al., 1990), cycloheximide added together with FK increased the NGF-mRNA level in an additive manner in Schwann cells. This result suggests that de novo synthesis of transcripticnal activators is not necessary for the effect of FK, which is consistent with the idea that posttranslational modification of preexisting CRE-binding factors might be involved (see reviews; Yamamoto et al., 1988). In contrast, transactivation of genes via AP-1 depends on de novo c-Fos protein synthesis (Schönthal et al., 1988).

Regulation of intracellular cAMP levels has been shown, at least in vitro, to be important for Schwann cell proliferation and differentiation (Raff et al., 1978; see, e.g., Sobue and Pleasure, 1984; Monuki et al., 1989). It is not clear which additional factors are needed to drive the cells in one direction or the other. The regulation of NGF-mRNA by cAMP elevation seems to be more or less independent of additional factors since it required only a very simple culture medium. Furthermore, it is interesting to note that cAMP increases NGF-mRNA transiently, whereas its effects on markers of differentiation, such as galactocerebroside and myelin gene induction, are observed for extended periods after treatment (Sobue and Pleasure, 1984; Monuki et al., 1989). It is not clear whether increases in cAMP content of Schwann cells occur also in vivo, and molecules responsible remain to be identified. Neurotransmitters and neuropeptides acting on receptors coupled to adenylate cyclase are candidates, but their accumulation to effective extracellular concentrations after nerve lesion has to be demonstrated. The presence of CGRP has been demonstrated in spinal motoneurons and dorsal root ganglion neurons (Rosenfeld et al., 1983; Gibson et al., 1984; Fontaine et al., 1986; New and Mudge, 1986; Villar et al., 1989). It is not known at present whether Schwann cells respond to CGRP by elevation of cAMP as has been demonstrated for myotubes (Laufer and Changeux, 1987; Villar et al., 1989).

In conclusion, a wide variety of different cell types, including several types of glial cells and neurons (for references, see Zafra et al., 1990), can express NGF. Together with previous investigations, we have shown here that even in one tissue, namely the sciatic nerve, different non-neuronal cell types show a surprising multiplicity of mechanisms of NGF regulation. To be able to exploit the potential therapeutical value of such studies, the molecular basis for these differences has to be worked out.

\section{References}

Aguayo AJ, Charron L, Bray GM (1976) Potential of Schwann cells from unmyelinated nerves to produce myelin: a quantitative ultrastructural and radiographic study. J Neurocytol 5:565-573.
Arakawa Y, Sendtner M, Thoenen H (1990) Survival effect of ciliary neurotrophic factor (CNTF) on chick embryonic motoneurons in culture: comparison with other neurotrophic factors and cytokincs. $J$ Neurosci 10:3507-3515.

Assouline JG, Bosch P, Lim R, Kim IS, Jensen R, Pantazis NJ (1987) Rat astrocytes and Schwann cells in culture synthesize nerve growth factor-like neurite promoting factors. Dev Brain Res 31:103-118.

Bandtlow C, Heumann R, Schwab ME, Thoenen H (1987) Cellular localization of nerve growth factor synthesis by in situ hybridization. EMBO J 6:891-899.

Beebe SJ, Holloway R, Rannels SR, Corbin JD (1984) Two classes of cAMP analogs which are selective for the different cAMP binding sites of type II protein kinase demonstrate synergism when added together to intact adipocytes. J Biol Chem 259:3539-3547.

Bottenstein J, Sato GH (1979) Growth of a rat neuroblastoma cell line in serum-free supplemented medium. Proc Natl Acad Sci USA 76:514-517.

Bunge MB, Williams AK, Wood PM, Uitto J, Jeffrey JJ (1980) Comparison of nerve cell and nerve cell plus Schwann cell cultures, with particular emphasis on basal lamina and collagen formation. J Cell Biol 84:184-202.

Bunge RP, Bunge MP, Eldridge CF (1986) Linkage between axonal ensheathment and basal lamina production by Schwann cells. Annu Rev Neurosci 9:305-328.

Carey DJ, Eldridge CF, Cornbrooks CJ, Timpl R, Bunge RP (1983) Biosynthesis of type IV collagen by cultured rat Schwann cells. J Cell Biol 97:473-479.

Chandler CE, Parsons LM, Hosang M, Shooter EM (1984) A monoclonal antibody modulates the interaction of nerve growth factor with PC12 cells. J Biol Chem 259:6882-6889.

Chomczynski P, Sacchi N (1987) Single-step method of RNA isolation by acid guanidium thiocyanate-phenol-chloroform extraction. Anal Biochem 162:156-159.

Cornbrooks CJ, Carey DJ, McDonald JA, Timpl R, Bunge RP (1983) In vivo and in vitro observations on laminin production by Schwann cells. Proc Natl Acad Sci USA 80:3850-3854.

Dal Toso R, De Bernardi MA, Brooker G, Costa E, Mocchetti I (1988) $B e t a$ adrenergic and prostaglandin receptor activation increases nerve growth factor mRNA content in C6-2B rat astrocytoma cells. J Pharmacol Exp Ther 246:1190-1 194.

Daniloff JK, Levi G, Grumet M, Rieger F, Edelman GM (1986) Altered expression of neuronal cell adhesion molcculcs induced by nerve injury and repair. J Cell Biol 103:929-945.

Davis JB, Stroobant P (1989) Platelet-derived growth factors and fibroblast growth factors are mitogens for rat Schwann cells. J Cell Biol 110:1353-1360.

DiStefano PS, Johnson EM (1988) Nerve growth factor receptors on cultured rat Schwann cells. J Neurosci 8:231-241.

Dubois-Dalcq M, Rentier B, Baron van Evercooren A, Burge BW (1981) Structure and behavior of rat primary and secondary Schwann cells in vitro. Exp Cell Res 131:283-297.

Eccleston PA, Jessen KR, Mirski R (1989) Transforming growth factor- $\beta$ and $\gamma$-interferon have dual effects on growth of peripheral gliat. J Neurosci Res 24:524-530.

Edelman AM, Blumenthal DK, Krebs EG (1987) Protein serine/threonine kinases. Annu Rev Biochem 56:567-613.

Fontaine B, Klarsfeld A, Hökfelt T, Changeux JP (1986) Calcitonin gene-related peptide, a peptide present in spinal motoneurons, increases the number of acetylcholine receptors in primary cultures of chick mytotubes. Neurosci Lett 71:59-65.

Gibson SJ, Polak JM, Bloom SR, Sabate IM, Mulderry PM, Ghatel MA, McGregor GP, Morrison JFB, Kelly JS, Evans RM, Rosenfeld MG (1984) Calcitonin gene-related peptide immunoreactivity in the spinal cord of man and of eight other species. J Neurosci 4:31013111.

Gonzalez GA, Yamamoto KK, Fischer WH, Karr D, Menzel P, Biggs W III, Vale WW, Montminy MR (1989) A cluster of phosphorylation sites on the cyclic AMP-regulated nuclear factor CREB predicted by its sequence. Nature 337:749-752.

Habener JF (1990) Cyclic AMP response element binding proteins: a cornucopia of transcription factors. Mol Endocrinol 4:1087-1094.

Hengerer B, Lindholm D, Heumann R, Rüther U, Wagner EF, Thoenen $H$ (1990) Lesion-induced increase in nerve growth factor mRNA is mediated by c-fos. Proc Natl Acad Sci USA 87:3899-3903.

Heumann R, Korsching S, Bandtlow C, Thoenen H (1987a) Changes 
of nerve growth factor synthesis in nonneuronal cells in response to sciatic nerve transection. J Cell Biol 104:1623-1631.

Heumann R, Lindholm D, Bandtlow C, Meyer M, Radeke MJ, Misko TP, Shooter E, Thoenen H (1987b) Differential regulation of mRNA encoding nerve growth factor and its receptor in rat sciatic nerve during development, degeneration, and regeneration: role of macrophages. Proc Natl Acad Sci USA 84:8735-8739.

Hidaka $H$, Hagiwara M, Chijiwa T (1989) Molecular pharmacology of protein kinases. Neurosci Res 15:431-434.

Hofer M, Barde Y-A (1988) Brain-derived neurotrophic factor prevents neuronal cell death in vivo. Nature 331:261-262.

Kerr LD, Miller DB, Matrisian LM (1990) TGF- $\beta 1$ inhibition on transin/stromelysin gene expression is mediated through a FOS binding sequence. Cell 61:267-278.

Korsching S, Thoenen H (1983) Nerve growth factor in sympathetic ganglia and corresponding target organs of the rat: correlation with density of sympathetic innervation. Proc Natl Acad Sci USA 80: 3513-3516.

Laufer R, Changeux JP (1987) Calcitonin gene-related peptide elevates cyclic AMP levels in chick skeletal muscle: possible neurotrophic role for a coexisting neuronal messenger. EMBO J 6:901-906.

Laurenza A, Sutkowski EM, Seamon KB (1989) Forskolin: a specific stimulator of adenylyl cyclase or a diterpene with multiple sites of action? Trends Pharmacol Sci 10:442-447.

Leibrock J, Lottspeich F, Hohn A, Hofer M, Hengerer B, Masiakowski P, Thoenen H, Barde Y-A (1989) Molecular cloning and expression of brain-derived neurotrophic factor. Nature 341:149-152.

Levi-Montalcini R, Angeletti PU (1968) Nerve growth factor. Physiol Rev 48:534-569.

Lin L-FH, Mismer D, Armes LG, Butler ET III, Vannice JL, Collins F (1989) Purification, cloning and expression of ciliary neurotrophic factor. Science 246:1023-1025.

Lindholm D, Heumann R, Meyer M, Thoenen H (1987) Interleukin-1 regulates synthesis of nerve growth factor in non-ncuronal cells of rat sciatic nerve. Nature 330:658-659.

Lindholm D, Heumann R, Hengerer B, Thoenen H (1988) Interleukin 1 increases stability and transcription of mRNA encoding nerve growth factor in cultured rat fibroblasts. J Biol Chem 263:16348-16351.

Lindholm D, Hengerer B, Zafra F, Thoenen H (1990) Transforming growth factor- $\beta 1$ stimulates expression of nerve growth factor in the rat CNS. Neuroreport 1:9-12.

McGarvey ML, Baron van Evercooren A, Kleinman HK, Dubois-Dalca M (1984) Synthesis and effects of basement membrane components in cultured rat Schwann cells. Dev Biol 105:18-28.

Mehta H, Orphe C, Todd MS, Cornbrooks CJ, Carey DJ (1985) Synthesis by Schwann cells of basal lamina and membrane-associated heparan sulfate proteoglycans. J Cell Biol 101:660-666.

Mocchetti I, De Bernardi MA, Szekely AM, Alho H, Brookcr G, Costa E (1989) Regulation of nerve growth factor biosynthesis by betaadrenergic receptor activation in astrocytoma cells: a potential role of c-Fos protein. Proc Natl Acad Sci USA 86:3891-3895.

Montminy MR, Gonzalez GA, Yamamoto KK (1990) Regulation of cAMP-inducible genes by CREB. Trends Neurosci 13:184-188.

Monuki ES, Weinmaster G, Kuhn R, Lemke G (1989) SCIP: a glial POU domain gene regulated by cyclic AMP. Neuron 3:783-793.

New HV, Mudge AW (1986) Calcitonin gene-related peptide regulates muscle acetylcholine receptor synthesis. Nature 323:809-811.

Nieke J, Schachner M (1985) Expression of the neural cell adhesion molecule N-CAM and $\mathrm{L} 1$ and their common carbohydrate epitope L2/HNK-1 during development and regeneration of sciatic nerve. Differentiation 30:141-151.

Noble M, Albrechtsen M, Möller C, Lyle J, Bock E, Goridis C, Watanabe M, Rutishauser U (1985) Glial cells express N-CAM/D2-CAM-like polypeptides in vitro. Nature 316:725-728.

Ohi T, Furukawa S, Hayashi K, Matsukura S (1990) Ganglioside stimulation of nerve growth factor synthesis in cultured rat Schwann cells. Biochem Int 20:739-746.

Porter S, Clark MB, Glaser L, Bunge RP (1986) Schwann cells stimulated to proliferate in the absence of neurons retain full functional capacity. J Neurosci 6:3070-3078

Raff MC, Hornby-Smith A, Brockes JP (1978) Cyclic AMP as a mitogenic signal for cultured rat Schwann cells. Nature 273:672-673.

Ratner N, Hong D, Lieberman M, Bunge RP, Glaser L (1988) The neuronal cell-surface molecule mitogenic for Schwann cells is a heparin binding protein. Proc Natl Acad Sci USA 85:6992-6996.
Richardson PM, Ebendal T (1982) Nerve growth activities in rat peripheral nerve. Brain Res 246:57-64.

Ridley A, Davis JB, Stroobant P, Land H (1989) Transforming growth factors- $\beta 1$ and $\beta 2$ are mitogens for rat Schwann cells. J Cell Biol 109: 3419-3424.

Rosenfeld MG, Mermod JJ, Amara SG, Swanson LW, Sawchenko PE, Rivier J, Vale WW, Evans RM (1983) Production of a novel neuropeptide encoded by the calcitonin gene via tissue-specific RNA processing. Nature 304:129-135.

Rozengurt E, Murray M, Zachary I, Collins M (1987) Protein kinase $C$ activation enhances cAMP accumulation in Swiss 3T3 cells: inhibition by pertussis toxin. Proc Natl Acad Sci USA 84:2282-2286.

Rush RA (1984) Immunohistochemical localization of endogenous nerve growth factor. Nature 312:364-367.

Rutkowski L, Needham L, Frayer K, Carson D, McKhann G, Tennekoon GI (1990) Evidence that secondary rat Schwann cells in culture maintain their differentiated phenotype. J Neurochem 54:1895-1904.

Saadat S, Sendtner M, Rohrer H (1989) Ciliary neurotrophic factor induces cholinergic differentiation of rat sympathetic neurons in culture. J Cell Biol 108:1807-1816.

Saksela O, Moscatelli D, Rifkin DB (1987) The opposing effects of basic fibroblast growth factor and transforming growth factor beta on the regulation of plasminogen activator activity in capillary endothelial cells. J Cell Biol 105:957-963.

Sasaki K, Cripe TP, Koch SR, Andreone T, Petersen DD, Beal EG, Granner DK (1984) Multihormonal regulation of phosphoenolpyruvate carboxykinase gene transcription. J Biol Chem 259:1524215251

Schmid E, Schmid W, Jantzen M, Mayer D, Jastorff B, Schütz G (1987) Transcription activation of the tyrosine aminotransferase gene by glucocorticoids and cAMP in primary hepatocytes. Fur J Biochem 165:499-506.

Schönthal A, Herrlich P, RahmsdorfHJ, Ponta H (1988) Requirement for fos gene expression in the transcriptional activation of collagenase by other oncogenes and phorbol ester. Cell 54:325-334.

Schwartz JP (1988) Stimulation of nerve growth factor mRNA content of $C 6$ glioma cells by a $\beta$-adrenergic receptor and by cyclic AMP. Glia 1:282-285.

Schwartz JP, Mishler K (1990) $\beta$-Adrenergic receptor regulation, through cyclic AMP, of nerve growth factor expression in rat cortical and cerebellar astrocytes. Cell Mol Neurobiol 10:447-457.

Seamon KB, Daly JW (1981) Forskolin: a unique diterpene activator of cyclic AMP-generating systems. J Cyclic Nucleotide Res 7:201224.

Shaw G, Kamen $R$ (1986) A conserved AU sequence from the 3 untranslated region of GM-CSF mRNA mediates selective mRNA degradation. Cell 46:659-667.

Sheng M, McFadden G, Greenberg ME (1990) Membrane depolarization and calcium induce c-fos transcription via phosphorylation of transcription factor CREB. Neuron 4:571-582.

Sobue G, Pleasure D (1984) Schwann cell galactocerebroside induced by derivatives of adenosine $3^{\prime}, 5^{\prime}$ monophosphate. Science 224:72-74.

Spranger M, Lindholm D, Bandtlow C, Heumann R, Gnahn H, NäherNoe M, Thoenen $H$ (1990) Regulation of nerve growth factor (NGF) synthesis in the rat central nervous system: comparison between the effects of interleukin-1 and various growth factors in astrocyte cultures and in vivo. Eur J Neurosci 2:69-76.

Stefansson K, Wollmann RL, Moore BW (1982) Distribution of S-100 protein outside the central nervous system. Brain Res 234:309317.

Stöckli KA, Lottspeich F, Sendtner M, Masiakowski P, Carroll P, Götz R, Lindholm D, Thoenen H (1989) Molccular cloning, cxpression and regional distribution of rat ciliary neurotrophic factor. Nature 342:920-923

Sugden D, Vanecek J, Klein DC, Thomas TP, Anderson WB (1985) Activation of protein kinase $C$ potentiates isoprenaline-induced cyclic AMP accumulation in rat pinealocytes. Nature 314:359-361

Thoenen H, Barde Y-A (1980) Physiology of nerve growth factor. Physiol Rev 60:1284-1335.

Van Nguyen T, Kobierski L, Comb M, Hyman SE (1990) The effect of depolarization on expression of the human proenkephalin gene is synergistic with cAMP and dependent upon a cAMP-inducible enhancer. J Neurosci 10:2825-2833.

Villar MJ, Roa M, Huchet M, Hökfelt T, Changeux J-P, Fahrenkrug J, Brown JC, Epstein M, Hersh L (1989) Immunoreactive calcitonin 
gene-related peptide, vasoactive intestinal polypeptide, and somatostatin in developing chicken spinal cord motorneurons: distribution and role in regulation of cAMP in cultured muscle cells. Eur J Neurosci 1:269-287.

Weinberg HJ, Spencer PS (1975) Studies on the control of myelinogenesis. II. Evidence for ncuronal regulation of myclin production. Brain Res 113:363-378.

Weinmaster G, Lemke G (1990) Cell-specific cyclic AMP-mediated induction of the PDGF receptor. EMBO J 9:915-920.

Wion D, MacGrogan D, Houlgatte R, Brachet P (1990) Phorbol $12-$ myristate 13-acetate (PMA) increases the expression of the nerve growth factor (NGF) gene in mouse L-929 fibroblasts. FEBS Lett 262: $42-44$

Wood PN, Bunge RP (1975) Evidence that sensory axons are mitogenic for Schwann cells. Nature 256:662-664.

Yamamoto KK, Gonzalez GA, Biggs WH III, Montminy MR (1988) Phosphorylation-induced binding and transcriptional efficacy of nuclear factor CREB. Nature 334:494-498.
Yasuda T, Sobue G, Mokuno K, Kreider B, Pleasure D (1987) Cultured rat Schwann cells express low affinity receptors for nerve growth factor. Brain Res 436:113-119.

Yasuda T, Sobue G, Mitsuma T, Takahashi A (1988) Peptidergic and adrenergic regulation of the intracellular $3^{\prime}, 5^{\prime}$-cyclic adenosine monophosphate content in cultured rat Schwann cells. J Neurol Sci 88: 315-325.

Yoshimasa T, Sibley DR, Bouvier M, Lefkovits RJ, Caron MG (1987) Cross-talk between cellular signalling pathways suggested by phorbolester-induced adenylate cyclase phosphorylation. Nature 327:67-70.

Zafra F, Hengerer B, Leibrock J, Thoenen H, Lindholm D (1990) Activity dependent regulation of BDNF and NGF mRNAs in the rat hippocampus is mediated by non-NMDA glutamate receptor. EMBO J 9:3545-3550.

Ziff EB (1990) Transcription factors: a new family gathers at the cAMP response site. Trends Genet 6:69-72. 